\title{
"Clicking" an Ionic Liquid to a Potent Antimicrobial Peptide: On the Route towards Improved Stability
}

\author{
Ana Gomes ${ }^{1}$, Lucinda J. Bessa ${ }^{1}{ }^{1}$, Patrícia Correia ${ }^{1}$, Iva Fernandes ${ }^{1}$, Ricardo Ferraz ${ }^{1,2} \mathbb{1}$, \\ Paula Gameiro ${ }^{1}$, Cátia Teixeira ${ }^{1}$ (D) and Paula Gomes ${ }^{1, *(\mathbb{D})}$ \\ 1 LAQV-REQUIMTE, Departamento de Química e Bioquímica, Faculdade de Ciências, Universidade do Porto, \\ P-4169-007 Porto, Portugal; anagomes@fc.up.pt (A.G.); lucinda.bessa@fc.up.pt (L.J.B.); \\ patricia.correia@fc.up.pt (P.C.); iva.fernandes@fc.up.pt (I.F.); ricardoferraz@eu.ipp.pt (R.F.); \\ agsantos@fc.up.pt (P.G.); catia.teixeira@fc.up.pt (C.T.) \\ 2 Ciências Químicas e das Biomoléculas, Escola Superior de Saúde, Politécnico do Porto, \\ P-4200-072 Porto, Portugal \\ * Correspondence: pgomes@fc.up.pt; Tel.: +35-12-2040-2563
}

Received: 6 July 2020; Accepted: 17 August 2020; Published: 26 August 2020

check for updates

\begin{abstract}
A covalent conjugate between an antibacterial ionic liquid and an antimicrobial peptide was produced via "click" chemistry, and found to retain the parent peptide's activity against multidrug-resistant clinical isolates of Gram-negative bacteria, and antibiofilm action on a resistant clinical isolate of Klebsiella pneumoniae, while exhibiting much improved stability towards tyrosinase-mediated modifications. This unprecedented communication is a prelude for the promise held by ionic liquids -based approaches as tools to improve the action of bioactive peptides.
\end{abstract}

Keywords: antibacterial; antibiofilm; ionic liquid; multidrug resistance; peptide; skin infections; tyrosinase; wound healing

\section{Introduction}

Ionic Liquids (ILs), though mostly known for their potential role as "green solvents", are becoming increasingly attractive as easily customizable and tunable organic salts for diverse specific purposes (task-specific ILs). There is an infinity of possibilities when combining organic cations with organic or inorganic anions, enabling production of ILs with diverse structural, physical and chemical properties [1] that can be adapted to the demands of areas as diverse as material sciences [2], biotechnology [3], or biomedicine [4]. Moreover, by making use of bioactive ions, ILs displaying relevant biological activities [5] can be produced, for instance, as anticancer [6], antimalarial [7], and antimicrobial agents [8].

ILs showing broad-spectrum activity against both Gram-negative and Gram-positive bacteria and antibiofilm activity have been reported [9]; as such, ILs are emerging as appealing alternatives to counteract antimicrobial resistance, while the world is running out of effective antibiotics, especially against Gram-negative bacteria. Moreover, many ILs have gained attention as dermal permeation enhancers [10], making them particularly attractive for topical applications. ILs presenting both antimicrobial activity and dermal permeation enhancement can be quite helpful to treat infected skin lesions, as recently demonstrated in an in vivo biofilm-infected wound assay, where an IL was able to kill $95 \%$ of the bacteria [11].

In view of the above, and based on our recent disclosure of a collagenesis-inducing peptide with potent antibacterial and antibiofilm properties [12], we now investigated the effect of coupling an antimicrobial methylimidazolium IL to the $N$-terminus of that peptide on antibacterial and antibiofilm activities, as well as on stability. To this end, we opted to use the well-known copper(I)-catalyzed 
alkyne-azide cycloaddition (CuAAC) "click" reaction, given its chemoselectivity and mildness, and the fact that it produces a stable triazole ring [13]. Moreover, CuAAC reactions have been previously used to introduce the triazole moiety in peptides aiming at, e.g., (i) replacing unstable bonds like disulfide bridges, (ii) improving peptide stability via cyclization, (iii) attaching distinct moieties and/or functional groups to the peptide, and (iv) taking advantage of the biological properties of many triazoles to improve overall bioactivity [14].

\section{Results and Discussion}

\subsection{Chemical Synthesis}

To produce the target IL-peptide conjugate, hereafter termed MeIm-3.1-PP4, the synthetic route shown in Scheme 1 was employed, starting with the synthesis of the alkyne-modified IL, by reacting 1-methylimidazole (MeIm) with propargyl bromide (step i), according to Hu et al. [15]; the structure of the target propargyl-MeIm (Pr-MeIm) was confirmed by proton $\left({ }^{1} \mathrm{H}\right)$ and carbon $\left({ }^{13} \mathrm{C}\right)$ nuclear magnetic resonance (NMR) and electrospray ionization-ion trap mass spectrometry (ESI-IT MS), as described in detail in the Supplementary Materials (Figures S1-S3). In parallel, the amino acid sequence of 3.1-PP4 was assembled by solid-phase peptide synthesis (SPPS, steps ii and iii) as previously reported by us [12]. Cleavage of half of the peptidyl-resin (step iv) afforded the parent peptide 3.1-PP4. The other half was coupled with azidoacetic acid (step v) to produce the azide-modified peptide; this was followed by on-resin CuAAC with Pr-MeIm (step vi), applying the conditions previously described by Castro et al. [16]. After cleavage and purification by reverse-phase high performance liquid chromatography (RP-HPLC), the target MeIm-3.1-PP4 conjugate was obtained in high purity (Figure S4), and its structure was confirmed by ESI-IT MS analysis (Figure S5). To the best of our knowledge, on-resin "clicking" of an ionic liquid to a peptide via the CuAAC has never been reported before.

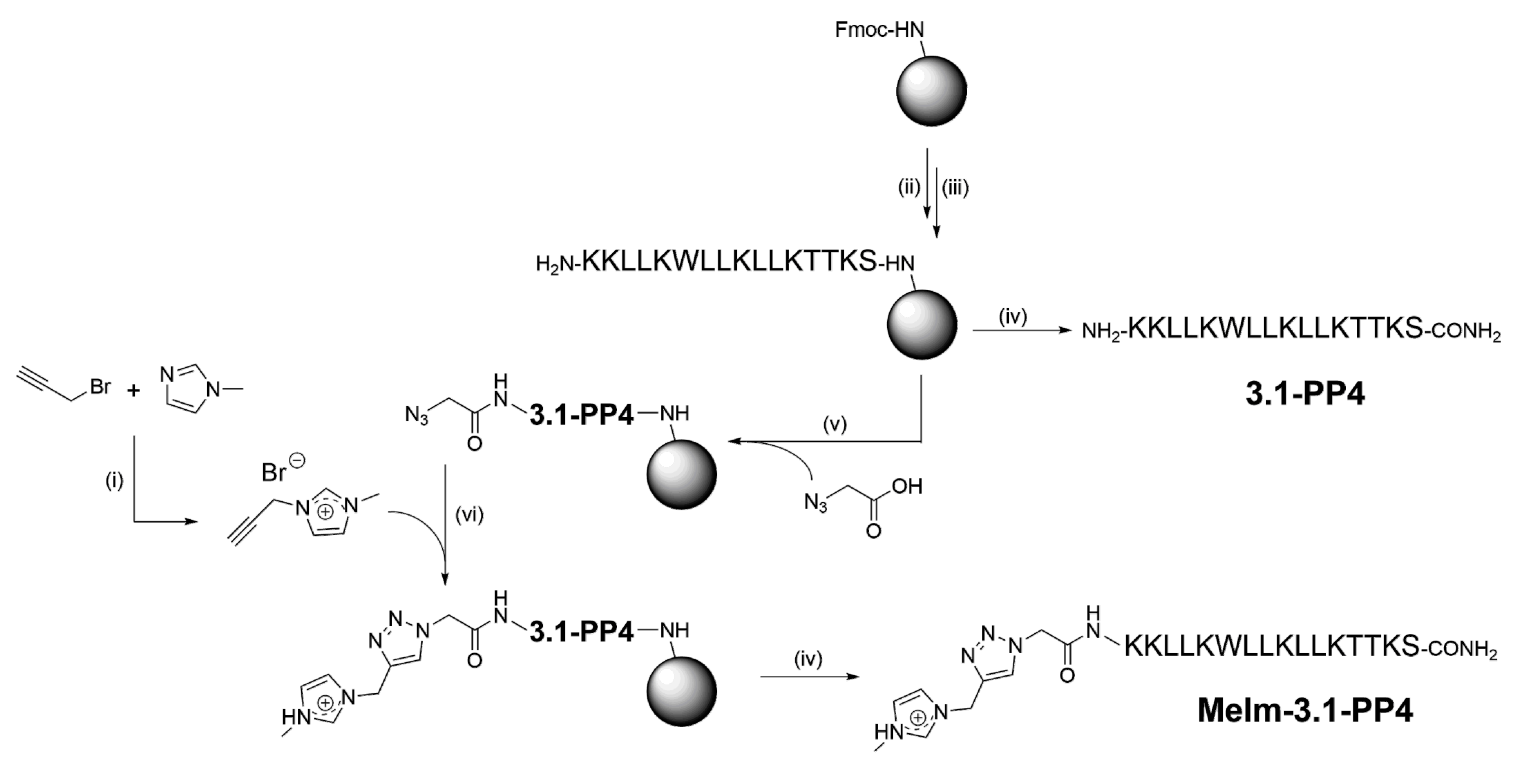

Scheme 1. Synthesis route towards MeIm-3.1-PP4: (i) 1.1 molar equivalents (eq) of MeIm, 1.0 eq of propargyl bromide (80\% in toluene), $40{ }^{\circ} \mathrm{C}$, 24 h; (ii) 5 eq of Fmoc-protected amino acid, 10 eq of $N$-ethyl- $N, N$-diisopropylamine (DIEA) and 5 eq of $O$-(benzotriazol-1-yl)- $N, N, N^{\prime}, N^{\prime}$-tetramethyluronium hexafluorophosphate (HBTU) in N,N-dimethylformamide (DMF), $1 \mathrm{~h}$, room temperature (r.t.); (iii) $20 \%$ piperidine in DMF, $15 \mathrm{~min}$, r.t.; (iv) trifluoroacetic acid (TFA)/triisopropylsilane (TIS)/distilled water (95:2.5:2.5 v/v/v), 2 h, r.t.; (v) 5 eq of azido acetic acid, 10 eq of DIEA, and 5 eq of HBTU in DMF, 1 h, r.t.; (vi) 1 eq sodium L- ascorbate, 10 eq of DIEA, 10 eq of 2,6-lutidine, 1 eq of Pr-MeIm, and 1 eq ofcopper(I) bromide in DMF:acetonitrile $(\mathrm{MeCN})(3: 1 v / v)$. 


\subsection{Antibacterial and Antibiofilm Activity}

Both the conjugate MeIm-3.1-PP4 and its parent peptide 3.1-PP4 were next screened for their antibacterial activity. Minimum inhibitory concentration (MIC) values were determined following the Clinical and Laboratory Standards Institute (CLSI) protocol [17], against Gram-positive (Staphylococcus aureus and Enterococcus faecalis), and Gram-negative (Pseudomonas aeruginosa, Escherichia coli and Klebsiella pneumoniae) bacteria, including both reference strains (American Type Culture Collection, ATCC), and multidrug-resistant (MDR) clinical isolates. Data thus obtained are shown in Table 1, and clearly demonstrate that, with only very few exceptions, attachment of the IL to the $N$-terminus of 3.1-PP4 did not significantly alter the antibacterial activity of the parent peptide. Relevantly, in most cases, MIC values matched the minimum bactericidal concentration (MBC) values, highlighting a bactericidal action for both MeIm-3.1-PP4 and its parent peptide.

Table 1. Minimum inhibitory concentrations (MIC) of MeIm-3.1-PP4 and its parent peptide, 3.1-PP4, against reference (American Type Culture Collection, ATCC) strains and multidrug-resistant (MDR) clinical isolates of Gram-positive and Gram-negative bacteria.

\begin{tabular}{|c|c|c|c|}
\hline \multirow{2}{*}{ Bacterial Species } & \multirow{2}{*}{$\begin{array}{l}\text { Reference Strain or } \\
\text { MDR Isolate }\end{array}$} & \multicolumn{2}{|c|}{$\mathrm{MIC}$ in $\mu \mathrm{g} / \mathrm{mL}$ (in $\mu \mathrm{M})$} \\
\hline & & 3.1-PP4 & MeIm-3.1-PP4 \\
\hline \multirow{4}{*}{ P. aeruginosa } & ATCC 27853 & $2.3(1.2)$ & $1.5(0.7)$ \\
\hline & PA004 & $1.3(0.7)$ & $3.1(1.4)$ \\
\hline & $\mathrm{Pa} 3$ & $1.3(0.7)$ & $1.5(0.7)$ \\
\hline & $\mathrm{Pa} 4$ & $1.3(0.7)$ & $0.8(0.4)$ \\
\hline \multirow{5}{*}{ E. coli } & ATCC 25922 & $1.3(0.7)$ & $0.8(0.4)$ \\
\hline & Ec2 & $1.3(0.7)$ & $1.5(0.7)$ \\
\hline & EC001 & $1.3(0.7)$ & $3.1(1.4)$ \\
\hline & EC002 & $1.3(0.7)$ & $1.5(0.7)$ \\
\hline & EC003 & $0.6(0.3)$ & $1.5(0.7)$ \\
\hline \multirow{2}{*}{ K. pneumoniae } & KP010 & $2.3(1.2)$ & $6.2(2.9)$ \\
\hline & KP004 & $2.3(1.2)$ & $49.6(23.1)$ \\
\hline \multirow{2}{*}{ S. aureus } & ATCC 25923 & $10.3(5.3)^{\mathrm{a}}$ & $24.8(11.6)^{\mathrm{a}}$ \\
\hline & SA007 & $10.3(5.3)$ & $12.4(5.8)$ \\
\hline \multirow{2}{*}{ E. faecalis } & ATCC 29212 & $41.3(21.3)$ & $99.3(46.3)$ \\
\hline & Ef1 & $2.3(1.2)^{a}$ & $3.1(1.4)$ \\
\hline
\end{tabular}

a Minimum bactericidal concentrations (MBC) were $2 \times$ the MIC; in all other cases, MBC equaled the MIC.

Since this type of IL-AMP conjugate is being developed for its potential interest to address infected skin lesions, a preliminary assessment of the toxicity of both the conjugate and the parent peptide towards HaCaT human epidermal keratinocytes was carried out by the 3-(4,5-dimethylthiazol-2-yl)-2,5-diphenyltetrazolium bromide (MTT) assay, as previously described by us [12]. Despite the $\mathrm{IC}_{50}(24 \mathrm{~h})$ obtained was somewhat lower for the conjugate $(19.4 \pm 0.2 \mu \mathrm{M})$ than for the parent peptide $(34.2 \pm 0.5 \mu \mathrm{M})$, the conjugate still exhibited selectivity indices ranging from ca. 14 to ca. 50 in most cases. In face of the excellent antibacterial properties exhibited by the MeIm-3.1-PP4 conjugate, especially against Gram-negative bacteria, we next evaluated its antibiofilm activity using the K. pneumoniae MDR isolate, KP010, since the parent peptide, 3.1-PP4, had previously displayed a more notable effect against this isolate [12]. This activity was assessed in two different ways: (i) inhibition of biofilm formation, and (ii) effect on a preformed biofilm. For evaluation of the inhibition of biofilm formation, both conjugate and parent peptide were tested at MIC and sub-inhibitory concentrations $\left(\frac{1}{2} \times \mathrm{MIC}\right.$ and at $\left.\frac{1}{4} \times \mathrm{MIC}\right)$ following previously established procedures [12,18-20], and the mass of biofilm formed at these concentrations was assessed through the crystal violet assay. Figure 1 shows results obtained in absence (control) and in presence of the test compounds at the three different concentrations. Relevantly, the absorbance measured for the control (absence of test compounds) 
provides confirmation that the bacterial strain used is a good biofilm producer [21]. As expected, only a little amount of biofilm was formed at MIC in both cases, with a slightly higher antibiofilm effect for the parent peptide. At sub-inhibitory concentrations $\left(\frac{1}{2} \times \mathrm{MIC}\right.$ and $\left.\frac{1}{4} \times \mathrm{MIC}\right)$, the biofilm biomasses formed remain lower than the control, in this case with a slightly stronger antibiofilm effect for the MeIm-3.1-PP4 conjugate.

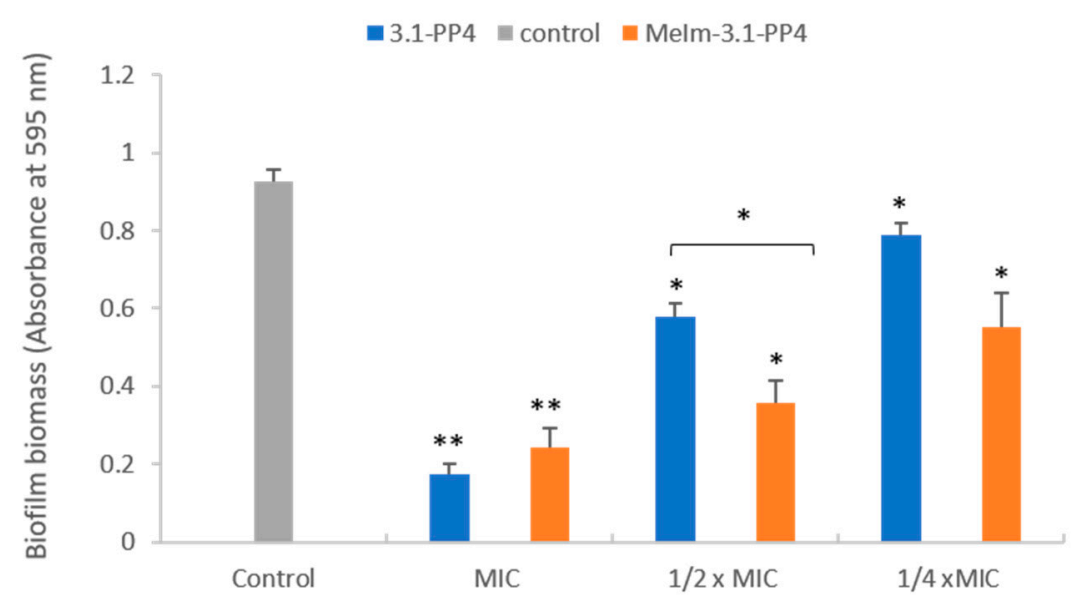

Figure 1. Effects of 3.1-PP4 and MeIm-3.1-PP4 on formation of K. pneumoniae KP010 biofilms (biomass quantification by crystal violet absorbance at $595 \mathrm{~nm}$ ). Three independent experiments were performed in triplicate and the bar errors represent the SD. Statistically significant differences between the biofilm formed in absence and in presence of peptide are indicated: ${ }^{*}$ means $(p<0.05)$ and ${ }^{* *}$ means $(p<0.01)$.

To assess the effects on preformed biofilms, much higher peptide concentrations are needed, hence biofilms of KP010 were allowed to grow for $48 \mathrm{~h}$ and then treated with the peptides at $20 \times$ the MIC value for $24 \mathrm{~h}$. Biofilm proliferation was determined by measuring the optical density (OD) of the planktonic phase of the biofilms, both treated with the test compounds and the untreated control. Results (Table S2 in Supplementary Materials) show that MeIm-3.1-PP4 and 3.1-PP4 caused a significant reduction in biofilm proliferation of $67 \%$ and $52 \%$, respectively. Overall, these results show that the novel IL-peptide conjugate preserves not only the antibacterial but also the antibiofilm properties of the parent peptide. This improvement, afforded by the insertion of the imidazolium motif, is in line with previous reports of enhanced antibacterial activity when combining imidazolium ILs with non-peptide antibiotics, like ampicillin, including against resistant bacterial strains [22].

\subsection{Enzymatic Stability}

One of our main motivations to explore IL-peptide conjugates concerns improving the enzymatic stability of the peptide moiety, as poor pharmacokinetics is a major obstacle towards clinical translation of AMP and other bioactive peptides, even when topical applications are envisaged. For instance, in a non-healing infected wound, peptides are vulnerable to modification by endogenous (e.g., tyrosinase, elastase, metalloproteinases) and exogenous (produced by colonizing microbes) enzymes in the wound site [23]. Peptide 3.1-PP4 and derivatives thereof are under investigation for topical applications on infected skin lesions; thus, to evaluate how the conjugation of an IL to 3.1-PP4 could affect the enzymatic stability of this peptide, we incubated both the conjugate and the parent peptide with tyrosinase, due to its central role in melanin biosynthesis in the skin [24], and reported increased levels in the course of wound healing [25]. The choice of this particular enzyme may seem odd at a first glance, as the 3.1-PP4 sequence lacks tyrosine residues, whereas tyrosinase is best known for promoting oxidation of phenols like, e.g., the side chain of tyrosine [25]. However, recent evidence of proteolytic activity for tyrosinase, with an apparent preference for hydrophobic amino acids, e.g., isoleucine, at the cleavage site [26], stimulated our interest in investigating whether our leucine-rich peptide would be a substrate for this enzyme of undeniable relevance in skin and wound healing. Hence, both parent 
peptide and its ionic liquid conjugate were incubated at $37^{\circ} \mathrm{C}$ and $\mathrm{pH} 6.8$ in the presence of the enzyme, and in its absence as a control. The samples were collected at different time points, for $24 \mathrm{~h}$, and were analyzed by HPLC. Results are presented in Figure 2, where the complete degradation, within $6 \mathrm{~h}$, of peptide 3.1-PP4 confirmed it as a substrate for tyrosinase, despite being devoid of tyrosine or any other phenol or polyphenol moieties. Additionally, about $84 \%$ of the IL-peptide conjugate MeIm-3.1-PP4 remained unaltered after $24 \mathrm{~h}$, demonstrating the remarkable gain in stability afforded by conjugation of the IL to the $\mathrm{N}$-terminus of the parent peptide. Both controls remained unchanged at the end of the experiment (data not shown).

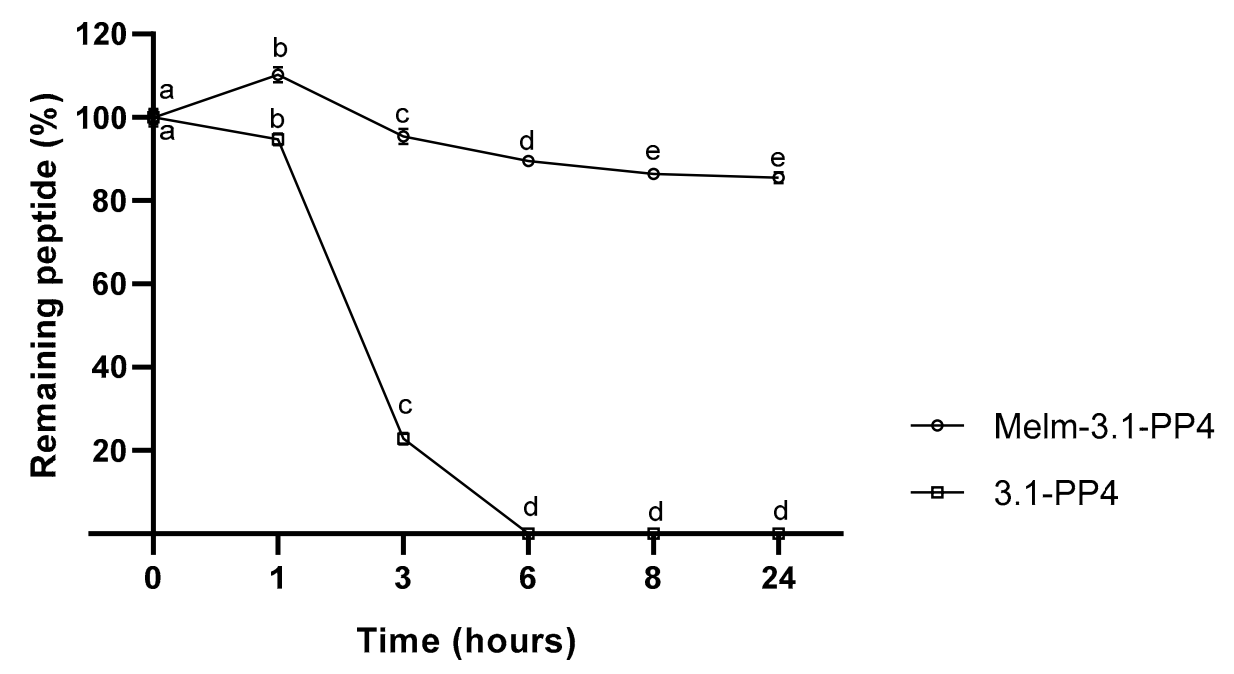

Figure 2. Compared stability of MeIm-3.1-PP4 and its parent peptide, upon incubation with tyrosinase (expressed as the variation of the \% of starting compound over time) of three independent experiments $(n=3)$. Values are expressed as mean \pm SD. Statistical significance, between the two test compounds for the same time point, was considered when $p<0.0001$, and observed for all time points. Statistical significance, between time points for the same compound, was considered when $p<0.05$ and is indicated by different letters.

The above findings are remarkable in two ways; (i) we confirm the recent observations by Biundo et al. in that tyrosinase can display promiscuous proteolytic activity [26], and (ii) we demonstrate that simple conjugation of an IL to the $N$-terminus of the peptide substrate prevents its degradation. Ongoing studies with these and other analogues will allow us to establish the pathway of peptide degradation by tyrosinase, and to ascertain how the peptide site at which the IL is conjugated (e.g., $C$-terminal rather than $N$-terminal conjugation) may influence enzymatic stability. Additional assays to evaluate conjugate's stability in the presence of more common enzymes and enzyme mixtures (trypsin, pronase), as well as other enzymes that are relevant in the context of chronic wounds (collagenase, elastase, metalloproteinases), will be timely carried out.

\section{Concluding Remarks}

In conclusion, this exploratory work holds great promise for the future, by demonstrating that "clicking" a classical imidazolium IL to the $N$-terminus of a bioactive peptide can preserve its potent antibacterial and antibiofilm action, while significantly improving its stability towards an enzyme that is relevant in the skin wound environment. To the best of our knowledge, despite previous reports that have addressed both covalent [27] and non-covalent [28] combinations of IL with peptides, there is no precedent in using click chemistry to create IL-AMP conjugates, nor in demonstrating the substantial stabilization observed against tyrosinase-mediated modification upon conjugation of an IL to an AMP. Ongoing studies will allow us to build a wider landscape of enzymatic stability for MeIm-3.1-PP4 and similar IL-peptide conjugates that are being produced, by including other analogues, and other 
enzymes relevant in the context of infected skin lesions and wound healing. Moreover, hemolysis assays will be carried out in order to establish whether conjugation to the IL renders the final conjugate more hemolytic than the parent peptide, at the light of previous literature reports [27,29]. Furthermore, in vitro wound healing and dermal permeation assays are under way that will allow us to further demonstrate the expected high value of this unprecedented approach. Finally, the potent action of the compounds herein reported against Gram-negative bacteria is noteworthy, since despite peptide-based structures with potent action against Gram-positive bacteria are being disclosed [30-33], the situation is quite different regarding MDR Gram-negative bacteria, against which real alternatives to current antibiotics remain elusive.

\section{Materials and Methods}

\subsection{Synthesis of 1-Methyl-3-Propargyl Imidazolium Bromide}

To a round-bottom flask containing 1-methylimidazole $(0.78 \mathrm{~mL} ; 9.89 \mathrm{mmol}), 80 \%$ propargyl bromide in toluene $(1 \mathrm{~mL} ; 8.99 \mathrm{mmol})$ was slowly added, and the deep yellow oily mixture formed was kept under stirring for $24 \mathrm{~h}$ at $40^{\circ} \mathrm{C}$. The mixture was then cooled down to r.t., and sequentially washed with dichloromethane (DCM, $10 \mathrm{~mL})$ and diethyl ether $(10 \mathrm{~mL})$ [15]. The resulting yellow oil was dried in a vacuum oven overnight, at $50{ }^{\circ} \mathrm{C}$ and 0.1 bar, to afford the final product in $77 \%$ yield. ${ }^{1} \mathrm{H},{ }^{13} \mathrm{C}$ NMR and ESI-IT MS analyses allowed to confirm the product as being the desired 1-methyl-3-propargyl imidazolium bromide, according to spectral data below (spectra obtained are displayed in the Supplementary Materials-Figures S1-S3). NMR spectra were acquired on a Bruker Avance III400 spectrometer from solutions of the compound in hexadeuterated dimethyl sulfoxide (DMSO-d6), containing tetramethylsilane (TMS) as internal reference. Multiplicity of proton NMR signals is given as: $\mathrm{s}$, singlet; $\mathrm{d}$, doublet; $\mathrm{t}$, triplet.

$\delta_{\mathrm{H}}(400 \mathrm{MHz}, \mathrm{DMSO}-\mathrm{d} 6) 9.27(\mathrm{~s}, 1 \mathrm{H}), 7.80(\mathrm{t}, 1 \mathrm{H}, \mathrm{J}=1.8 \mathrm{~Hz}), 7.76(\mathrm{t}, 1 \mathrm{H}, \mathrm{J}=1.8 \mathrm{~Hz}), 5.22(\mathrm{~d}, 2 \mathrm{H}$, $\mathrm{J}=2.6 \mathrm{~Hz}), 3.88(\mathrm{~s}, 3 \mathrm{H}), 3.84(\mathrm{t}, 1 \mathrm{H}, \mathrm{J}=2.6 \mathrm{~Hz}) . \delta_{\mathrm{C}}(100 \mathrm{MHz}, \mathrm{DMSO}-\mathrm{d} 6)$ 136.3, 124.1, 122.1, 79.0, 76.1, $38.5,36.0(\mathrm{ESI}+) \mathrm{m} / \mathrm{z}$ calculated for $\mathrm{C}_{7} \mathrm{H}_{9} \mathrm{~N}_{2}{ }^{+}, 121.08$; found, 121.20.

\subsection{Peptide Synthesis}

The amino acid sequence of 3.1-PP4 (KKLLKWLLKLLKTTKS, C-terminal amide) was assembled by SPPS, using the standard Fmoc/ ${ }^{t} \mathrm{Bu}$ orthogonal protection scheme [34]. Briefly, Fmoc-Rink-amide MBHA resin (100-200 mesh, $0.52 \mathrm{mmol} / \mathrm{g}$ ) was swelled in DMF for $30 \mathrm{~min}$, next treated with an excess of $20 \%$ piperidine in DMF for $15 \mathrm{~min}$ (r.t.); after several washing steps using DMF $(3 \times 10 \mathrm{~mL})$ and $\operatorname{DCM}(3 \times 10 \mathrm{~mL})$, the Fmoc-protected $C$-terminal amino acid (5 eq) was coupled to the resin in the presence of the in situ coupling agent HBTU (5 eq) and the non-nucleophilic base DIEA (10 eq) in DMF, for $1 \mathrm{~h}$ at r.t., under stirring. After a few quick washing steps as before, the Fmoc group was removed with piperidine as above, and the coupling $\rightarrow$ deprotection cycle was repeated until the full amino acid sequence was assembled. At this stage, the peptidyl-resin was split in two equal portions, one of which was reserved for the subsequent stage (synthesis of MeIm-3.1-PP4, see Section 4.3). Peptide 3.1-PP4 was cleaved off the other portion of the peptidyl-resin via acidolytic cleavage with a cocktail containing 95\% TFA, 2.5\% TIS and 2.5\% distilled water, for $2 \mathrm{~h}$ under stirring at r.t.. The crude peptide was then purified by preparative RP-HPLC, on a Hitachi-Merck LaPrep Sigma system using a C18 column $(250 \times 25 \mathrm{~mm}$ ID, $5 \mu \mathrm{m}$ pore size). The elution gradient of 1 to $100 \%$ of $\mathrm{MeCN}$, used $0.05 \%$ aqueous TFA as solvent $\mathrm{A}$ and $\mathrm{MeCN}$ as solvent $\mathrm{B}$, and was run for $60 \mathrm{~min}$ at $15 \mathrm{~mL} / \mathrm{min}$. Fractions containing pure peptide were pooled, and an aliquot was taken to assess final purity degree by HPLC and confirm the expected molecular weight by ESI-IT MS, as previously described [17]. The final peptide solution was freeze-dried and stored at $-20^{\circ} \mathrm{C}$ until further use. 


\subsection{Synthesis of MeIm-3.1-PP4}

To the reserved portion of peptidyl-resin having the 3.1-PP4 sequence fully assembled (see Section 4.2), a solution containing azidoacetic acid ( $18.7 \mathrm{~mL} ; 5 \mathrm{eq})$, DIEA ( $85 \mathrm{~mL} ; 10 \mathrm{eq})$, and HBTU (64 mg; 5 eq) in DMF was added, and the slurry kept under stirring for $1 \mathrm{~h}$ at r.t. After quick washing steps with DMF and DCM, as described in Section 4.2, a solution containing sodium L-ascorbate $(10 \mathrm{mg}$; 1 eq), DIEA ( $85 \mathrm{~mL} ; 10 \mathrm{eq}), 2,6$-lutidine ( $58 \mathrm{~mL} ; 10 \mathrm{eq}$ ), and 1-methyl-3-propargyl imidazolium bromide (10 mg; 1 eq) in DMF ( $3 \mathrm{~mL}$ ) was added, followed by addition of a solution of copper(I) bromide ( $7 \mathrm{mg} ; 1 \mathrm{eq})$ in $\mathrm{MeCN}(1 \mathrm{~mL})$. The reaction was allowed to proceed at r.t. for $24 \mathrm{~h}$, under stirring. Then, the resin was thoroughly washed with $1 \mathrm{M}$ aqueous ethylenediaminetetraacetic acid (EDTA, $5 \times 10 \mathrm{~mL}$ ), followed by DMF and DCM as before. The crude product was cleaved from the resin via acidolysis, as in 4.2, and found (LC-MS) to be a mixture of the target conjugate (ca. 97\%) and unreacted azido-peptide (ca. $2 \%$ ), amongst other minor unidentified components, probably corresponding to truncated peptides (data not shown). The crude product was purified by preparative RP-HPLC, as done before for the parent 3.1-PP4 peptide (see Section 4.2). The pure conjugate was analyzed by HPLC (Figure S4) and ESI-IT MS (Figure S5), freeze-dried and stored at $-20{ }^{\circ} \mathrm{C}$ until further use.

\subsection{Peptide Quantitation}

Peptide 3.1-PP4 and conjugate MeIm-3.1-PP4 stock solutions were prepared in distilled water at ca. $10 \mathrm{mg} / \mathrm{mL}$. Concentration was then accurately determined on a Thermo Scientific ${ }^{\mathrm{TM}}$ NanoDrop $^{\mathrm{TM}}$ One microvolume UV-Vis Spectrophotometer, using method 31 that assumes an extinction coefficient $\varepsilon_{205}$ of $31 \mathrm{mLmg}^{-1} \mathrm{~cm}^{-1}$ and an $\mathrm{A}_{280} / \mathrm{A}_{205}$ correction for the absorbance due to tryptophan (Trp) and tyrosine (Tyr) residues eventually present (only Trp was present in this case) [35].

\subsection{Antibacterial Activity Assays}

The MIC of the test compounds was determined according to the CLSI guidelines [17]. Briefly, the compounds were tested in the $1-1024 \mu \mathrm{g} / \mathrm{mL}$ concentration range, using the microdilution method in cation-adjusted Mueller-Hinton broth (MHB II) against reference strains of P. aeruginosa ATCC 27853, E. coli ATCC 25922, S. aureus ATCC 25923, and Enterococcus faecalis ATCC 29212. MIC values were also determined against MDR clinical isolates (antibiotic resistance patterns given in Supplementary Materials, Table S1) of P. aeruginosa (PA004, Pa3, Pa4), E. coli (Ec2, EC001, EC002, EC003), K. pneumoniae (KP004, KP010), S. aureus (SA007), and Enterococcus faecalis (Ef1). Along with the MIC values, MBC values were also determined as previously reported [12].

\subsection{Toxicity to Human Keratinocytes}

The cytotoxicity of peptides to HaCat cells was evaluated using the standard MTT assay. Briefly, cells were seeded at a density of $4 \times 10^{4}$ cells/mL, respectively, in 96-well plates and incubated at 37 ${ }^{\circ} \mathrm{C}$ in a $5 \% \mathrm{CO}_{2}$ atmosphere. Cells were allowed to grow for $24 \mathrm{~h}$, and serially diluted compound solutions $(6.3-100 \mu \mathrm{M})$ were added to the wells. Then, cells were incubated for $24 \mathrm{~h}$ at $37^{\circ} \mathrm{C}$, after which wells were washed once with phosphate buffered saline (PBS, Sigma-Aldrich), followed by addition of a $0.45 \mathrm{mg} / \mathrm{mL}$ MTT solution to each well. Crystals were allowed to form for $1.5 \mathrm{~h}$. Reaction was stopped by rejecting the medium followed by addition of dimethylsulfoxide (DMSO, Sigma-Aldrich). Absorbance was read at $570 \mathrm{~nm}$ in FlexStation ${ }^{\circledR} 3$ Multi-Mode Microplate Reader (Molecular Devices, San Jose, CA, USA).

\subsection{Antibiofilm Activity Assays}

The ability of the test compounds to inhibit the biofilm formation by KP010 (a MDR clinical isolate of $K$. pneumoniae) was assessed at the respective MIC, $1 / 2 \times$ MIC and $1 / 4 \times$ MIC values in tryptic soy broth (TSB) using the crystal violet assay as previously reported [36,37]. Three independent experiments were performed in triplicate for each condition. 
To assess the effects of test compounds on $48 \mathrm{~h}$ preformed biofilms of KP010, the biofilms were first grown in TSB from a starting inoculum of $1 \times 10^{6} \mathrm{CFU} / \mathrm{mL}$ in 96-well microtiter plates. After $48 \mathrm{~h}$ of incubation at $37^{\circ} \mathrm{C}$, the planktonic cells were removed, and the wells were rinsed and filled with the test compound at a $20 \times \mathrm{MIC}$ concentration. The optical density at $600 \mathrm{~nm}$ was measured at time 0 and after incubation for $24 \mathrm{~h}$ at $37^{\circ} \mathrm{C}$. The reduction in the biofilm proliferation was calculated in comparison to the respective non-treated biofilms. Three independent experiments were performed in triplicate.

\subsection{Enzymatic Stability Assays}

The IL-peptide conjugate and the parent peptide were both incubated at a final concentration of $10 \mathrm{mM}$ in phosphate buffer ( $\mathrm{pH}$ 6.8), with the enzyme tyrosinase (CAS:9002-10-2; T3824-250KU) at $18 \mathrm{U} / \mathrm{mL}$, for $24 \mathrm{~h}$ at $37^{\circ} \mathrm{C}$. Then, $150-\mu \mathrm{L}$ samples were collected after $0,1,3,6,8$ and $24 \mathrm{~h}$ of incubation, and $150 \mu \mathrm{L}$ of methanol were added to each of them to precipitate the enzyme. The mixtures were centrifuged at $1.05 \times 10^{4} \mathrm{RPM}$ for 2 min with an Eppendorf miniSpin centrifuge (rotor F-45-12-11). The supernatant was then analyzed by HPLC, using a Hitachi-Merck LaChrom Elite system with a reverse-phase $\mathrm{C} 18$ column $(125 \times 40 \mathrm{~mm}$ ID and $5 \mu \mathrm{m}$ pore size). The analyses were run, in triplicates, at a flow rate of $1 \mathrm{~mL} / \mathrm{min}$ with a solvent gradient of 1 to $100 \%$ of $\mathrm{B}$ in $\mathrm{A}$, using $0.05 \%$ aqueous TFA as solvent $\mathrm{A}$ and $\mathrm{MeCN}$ as solvent $\mathrm{B}$, for $30 \mathrm{~min}$, with a $220 \mathrm{~nm}$ detection wavelength.

\subsection{Statistical Analysis}

The results regarding the biofilm formation and preformed biofilms were expressed as mean values \pm standard deviation (mean \pm SD). The statistical significance of differences between controls and experimental groups was evaluated using the Student's $t$-test. $p$-values of $<0.05$ were considered statistically significant.

Results from peptide stability were expressed as the variation of the \% of starting compound over time (mean \pm SD). Data were analyzed in GraphPad Prism 8.0.1 Software using two-way analysis of variance (ANOVA) followed by Tukey's multiple comparison test. Statistical significance was considered when $p<0.05$.

Supplementary Materials: Supplementary Materials can be found at http://www.mdpi.com/1422-0067/21/17/ 6174/s1. Figures S1-S5, and Tables S1-S2.

Author Contributions: Conceptualization, C.T., R.F., P.G. (Paula Gameiro), L.J.B., P.G. (Paula Gomes); Investigation, A.G., P.C., I.F., C.T., L.J.B.; Writing-Original Draft, A.G., L.J.B., I.F., P.G. (Paula Gomes).; Writing-Review \& Editing, C.T., R.F., P.G. (Paula Gameiro), L.J.B., I.F., P.G. (Paula Gomes); Supervision, R.F., P.G. (Paula Gameiro), C.T., P.G. (Paula Gomes). All authors have read and agreed to the published version of the manuscript.

Funding: This research was funded by FUNDAÇÃO PARA A CIÊNCIA E TECNOLOGIA (FCT, Portugal), through grants UIDB/50006/2020 (to LAQV-REQUIMTE Research Unit), PTDC/NAN-MAT/31781/2017 (ANTINFECT Project Grant), PD/BD/135073/2017 (Doctoral grant to Ana Gomes), and SFRH/BPD/86173/2012 (Research Contract to Iva Fernandes).

Acknowledgments: Thanks are also due to the Portuguese NMR network (RNRMN), for support to the Laboratory for Structural Elucidation (LAE) of the Materials Centre of the University of Porto (CEMUP).

Conflicts of Interest: The authors declare no conflict of interest. 


\section{Abbreviations}

\begin{tabular}{|c|c|}
\hline AMP & Antimicrobial peptide \\
\hline ATCC & American Type Culture Collection \\
\hline CFU & Colony-forming units \\
\hline CLSI & Clinical and Laboratory Standards Institute \\
\hline CuAAC & Copper(I)-catalyzed azide alkyne cycloaddition \\
\hline DCM & Dichloromethane \\
\hline DIEA & $N$-ethyl- $N, N$-diisopropylamine \\
\hline DMF & Dimethylformamide \\
\hline DMSO & Dimethylsulfoxide \\
\hline DMSO-d6 & Hexadeuterated dimethylsulfoxide \\
\hline EDTA & Ethylenediaminetetraacetic acid \\
\hline eq & Molar equivalent \\
\hline ESI-IT MS & Electrospray ionization-ion trap mass spectrometry \\
\hline Fmoc & 9-fluorenylmethoxycarbonyl \\
\hline $\mathrm{HaCaT}$ & Human epidermal keratinocytes \\
\hline HBTU & O-(benzotriazol-1-yl)- $N, N, N^{\prime}, N^{\prime}$-tetramethyluronium hexafluorophosphate \\
\hline HPLC & High performance liquid chromatography \\
\hline IL & Ionic Liquid \\
\hline $\mathrm{MBC}$ & Minimum bactericidal concentration \\
\hline MDR & Multidrug-resistant \\
\hline $\mathrm{MeCN}$ & Acetonitrile \\
\hline MeIm & 1-methylimidazole \\
\hline MHB II & Cation-adjusted Mueller-Hinton broth \\
\hline MIC & Minimum inhibitory concentration \\
\hline MTT & 3-(4,5-dimethylthiazol-2-yl)-2,5-diphenyltetrazolium bromide \\
\hline NMR & Nuclear magnetic resonance \\
\hline OD & Optical density \\
\hline PBS & Phosphate buffered saline \\
\hline Pr-MeIm & Propargyl-1-methylimidazole \\
\hline RP-HPLC & Reverse-phase high performance liquid chromatography \\
\hline r.t. & Room temperature \\
\hline SD & Standard deviation \\
\hline TFA & Trifluoroacetic acid \\
\hline TIS & Triisopropylsilane \\
\hline TMS & Tetramethylsilane \\
\hline TSB & Tryptic soy broth \\
\hline
\end{tabular}

\section{References}

1. Egorova, K.S.; Ananikov, V.P. Fundamental importance of ionic interactions in the liquid phase: A review of recent studies of ionic liquids in biomedical and pharmaceutical applications. J. Mol. Liq. 2018, 272, 271-300. [CrossRef]

2. Torimoto, T.; Tsuda, T.; Okazaki, K.-I.; Kuwabata, S. New Frontiers in Materials Science Opened by Ionic Liquids. Adv. Mater. 2010, 22, 1196-1221. [CrossRef] [PubMed]

3. Roosen, C.; Müller, P.; Greiner, L. Ionic liquids in biotechnology: Applications and perspectives for biotransformations. Appl. Microbiol. Biotechnol. 2008, 81, 607-614. [CrossRef] [PubMed]

4. Egorova, K.S.; Gordeev, E.G.; Ananikov, V.P. Biological Activity of Ionic Liquids and Their Application in Pharmaceutics and Medicine. Chem. Rev. 2017, 117, 7132-7189. [CrossRef] [PubMed]

5. Ferraz, R.; Branco, L.C.; Prudêncio, C.; Noronha, J.P.; Petrovski, Z. Ionic liquids as active pharmaceutical ingredients. ChemMedChem 2011, 6, 975-985. [CrossRef]

6. Dias, A.R.; Costa-Rodrigues, J.; Fernandes, M.H.; Ferraz, R.; Prudêncio, C. The Anticancer Potential of Ionic Liquids. ChemMedChem 2017, 12, 11-18. [CrossRef] 
7. Ferraz, R.; Pinheiro, M.; Gomes, A.; Teixeira, C.; Prudêncio, C.; Reis, S.; Gomes, P. Effects of novel triple-stage antimalarial ionic liquids on lipid membrane models. Bioorg. Med. Chem. Lett. 2017, 27, 4190-4193. [CrossRef]

8. Pendleton, J.N.; Gilmore, B.F. The antimicrobial potential of ionic liquids: A source of chemical diversity for infection and biofilm control. Int. J. Antimicrob. Agents 2015, 46, 131-139. [CrossRef]

9. Venkata Nancharaiah, Y.; Reddy, G.K.; Lalithamanasa, P.; Venugopalan, V.P. The ionic liquid 1-alkyl-3-methylimidazolium demonstrates comparable antimicrobial and antibiofilm behavior to a cationic surfactant. Biofouling 2012, 28, 1141-1149. [CrossRef]

10. Sidat, Z.; Marimuthu, T.; Kumar, P.; du Toit, L.C.; Kondiah, P.P.D.; Choonara, Y.E.; Pillay, V. Ionic Liquids as Potential and Synergistic Permeation Enhancers for Transdermal Drug Delivery. Pharmaceutics 2019, 11, 96. [CrossRef]

11. Zakrewsky, M.; Lovejoy, K.S.; Kern, T.L.; Miller, T.E.; Le, V.; Nagy, A.; Goumas, A.M.; Iyer, R.S.; Del Sesto, R.E.; Koppisch, A.T.; et al. Ionic liquids as a class of materials for transdermal delivery and pathogen neutralization. Proc. Natl. Acad. Sci. USA 2014, 111, 13313-13318. [CrossRef] [PubMed]

12. Gomes, A.; Bessa, L.J.; Fernandes, I.; Ferraz, R.; Mateus, N.; Gameiro, P.; Teixeira, C.; Gomes, P. Turning a Collagenesis-Inducing Peptide Into a Potent Antibacterial and Antibiofilm Agent Against Multidrug-Resistant Gram-Negative Bacteria. Front. Microbiol. 2019, 10. [CrossRef] [PubMed]

13. Ahmad Fuaad, A.; Azmi, F.; Skwarczynski, M.; Toth, I. Peptide Conjugation via CuAAC 'Click' Chemistry. Molecules 2013, 18, 13148-13174. [CrossRef] [PubMed]

14. Li, H.; Aneja, R.; Chaiken, I. Click chemistry in peptide-based drug design. Molecules 2013, 18, $9797-9817$. [CrossRef] [PubMed]

15. Hu, Q.; Deng, Y.; Yuan, Q.; Ling, Y.; Tang, H. Polypeptide ionic liquid: Synthesis, characterization, and application in single-walled carbon nanotube dispersion. J. Polym. Sci. Part A Polym. Chem. 2014, 52, 149-153. [CrossRef]

16. Castro, V.; Rodriguez, H.; Albericio, F. Wang Linker Free of Side Reactions. Org. Lett. 2013, 15, $246-249$. [CrossRef]

17. Patel, J.B.; Cockerill, F.R., III. CLSI, Methods for Dilution Antimicrobial Susceptibility Tests for Bacteria That Grow Aerobically-Ninth Edition: Approved Standard M7-A9; Clinical and Laboratory Standards Institute: Wayne, PA, USA, 2012.

18. Bessa, L.J.; Manickchand, J.R.; Eaton, P.; Leite, J.R.S.A.; Brand, G.D.; Gameiro, P. Intragenic antimicrobial peptide $\mathrm{Hs} 02$ hampers the proliferation of single- and dual-species biofilms of P. aeruginosa and S. aureus: A promising agent for mitigation of biofilm-associated infections. Int. J. Mol. Sci. 2019, 20, 3604. [CrossRef]

19. Overhage, J.; Campisano, A.; Bains, M.; Torfs, E.C.W.; Rhem, B.H.A.; Hancock, R.E.W. Human host defense peptide LL-37 prevents bacterial biofilm formation. Infect. Immun. 2008, 4176-4182. [CrossRef]

20. Lin, Q.; Deslouches, B.; Montelaro, R.B.; Di, Y.P. Prevention of ESKAPE pathogen biofilm formation by antimicrobial peptides WLBU2 and LL37. Int. J. Antimicrob. Agents 2018, 52, 667-672. [CrossRef]

21. Stepanović, S.; Vuković, D.; Hola, V.; Di Bonaventura, G.; Djukić, S.; Cirković, I.; Ruzicka, F. Quantification of biofilm in microtiter plates: Overview of testing conditions and practical recommendations for assessment of biofilm production by staphylococci. APMIS 2007, 115, 891-899. [CrossRef]

22. Costa, F.; Teixeira, C.; Gomes, P.; Martins, M.C.L. Clinical Application of AMPs. Adv. Exp. Med. Biol. 2019, 1117, 281-298. [CrossRef] [PubMed]

23. Grönberg, A.; Zettergren, L.; Agren, M.S. Stability of the cathelicidin peptide LL-37 in a non-healing wound environment. Acta Derm. Venereol. 2011, 91, 511-515. [CrossRef] [PubMed]

24. Panzella, L.; Napolitano, A. Natural and Bioinspired Phenolic Compounds as Tyrosinase Inhibitors for the Treatment of Skin Hyperpigmentation: Recent Advances. Cosmetics 2019, 6, 57. [CrossRef]

25. Süntar, I.; Akkol, E.K.; Senol, F.S.; Keles, H.; Orhan, I.E. Investigating wound healing, tyrosinase inhibitory and antioxidant activities of the ethanol extracts of Salvia cryptantha and Salvia cyanescens using in vivo and in vitro experimental models. J. Ethnopharmacol. 2011, 135, 71-77. [CrossRef]

26. Biundo, A.; Braunschmid, V.; Pretzler, M.; Kampatsikas, I.; Darnhofer, B.; Birner-Gruenberger, R.; Rompel, A.; Ribitsch, D.; Guebitz, G.M. Polyphenol oxidases exhibit promiscuous proteolytic activity. Commun. Chem. 2020, 3, 62. [CrossRef]

27. Reihardt, A.; Horn, M.; Schmauck, J.P.; Bröhl, A.; Giernoth, R.; Oelkrug, C.; Neundorf, I. Novel imidazolium salt-peptide conjugates and their antimicrobial activity. Bioconj. Chem. 2014, 25, 2166-2174. [CrossRef] 
28. Saraswat, J.; Wani, F.A.; Dar, K.I.; Rizvi, M.M.A.; Patel, R. Noncovalent conjugates of ionic liquid with antibacterial peptide melittin: An eficiente combination against bacterial cells. ACS Omega 2020, 5, 6376-6388. [CrossRef]

29. Frade, R.F.M.; Afonso, C.A.M. Impact of ionic liquids in environment and humans. Hum. Exp. Toxicol. 2010, 29, 1038-1054. [CrossRef]

30. Tally, F.P.; DeBruin, M.F. Development of daptomycin for Gram-positive infections. J. Antimicrob. Chemother. 2000, 46, 523-526. [CrossRef]

31. Ling, L.L.; Schneider, T.; Peoples, A.J.; Spoering, A.L.; Engels, I.; Conlon, B.P.; Mueller, A.; Schäberle, T.F.; Hughes, D.E.; Epstein, S.; et al. A new antibiotic kills pathogens without detectable resistance. Nature 2015, 517, 455. [CrossRef]

32. Zipperer, A.; Konnerth, M.C.; Laux, C.; Berscheid, A.; Janek, D.; Weidenmaier, C.; Burian, M.; Schilling, N.A.; Slavetinsky, C.; Marschal, M.; et al. Human commensals producing a novel antibiotic impair pathogen colonization. Nature 2016, 535, 511-516. [CrossRef]

33. Matsui, K.; Kan, Y.; Kikuchi, J.; Matsushima, K.; Takemura, M.; Maki, H.; Kozono, I.; Ueda, T.; Minagawa, K. Stalobacin: Discovery of Novel Lipopeptide Antibiotics with Potent Antibacterial Activity against Multidrug-Resistant Bacteria. J. Med. Chem. 2020, 63, 6090-6095. [CrossRef] [PubMed]

34. Behrendt, R.; White, P.; Offer, J. Advances in Fmoc solid-phase peptide synthesis. J. Pept. Sci. 2016, 22 , 4-27. [CrossRef] [PubMed]

35. Loughrey, S.; Mannion, J.; Matlock, B. Using the NanoDrop One to Quantify Protein and Peptide Preparations at $205 \mathrm{~nm}$. Available online: http://tools.thermofisher.com/content/sfs/brochures/ND-One-Protein-andPeptide-r16-01-18.pdf (accessed on 7 August 2020).

36. Bessa, L.J.; Eaton, P.; Dematei, A.; Plácido, A.; Vale, N.; Gomes, P.; Delerue-Matos, C.; Sa Leite, J.R.; Gameiro, P. Synergistic and antibiofilm properties of ocellatin peptides against multidrug-resistant Pseudomonas aeruginosa. Future Microbiol. 2018, 13, 151-163. [CrossRef] [PubMed]

37. Gomes, N.M.; Bessa, L.J.; Buttachon, S.; Costa, P.M.; Buaruang, J.; Dethoup, T.; Silva, A.M.; Kijjoa, A. Antibacterial and antibiofilm activities of tryptoquivalines and meroditerpenes isolated from the marine-derived fungi Neosartorya paulistensis, N. laciniosa, N. tsunodae, and the soil fungi N. fischeri and N. siamensis. Mar. Drugs 2014, 12, 822-839. [CrossRef]

(C) 2020 by the authors. Licensee MDPI, Basel, Switzerland. This article is an open access article distributed under the terms and conditions of the Creative Commons Attribution (CC BY) license (http://creativecommons.org/licenses/by/4.0/). 